\title{
ANALYZING THE RELATIONSHIP BETWEEN TYPES OF ADVERTISEMENT AND CUSTOMER CHOICE : A STUDY OF RETAILER STORES IN ERBIL
}

\author{
Raghda Climis ${ }^{1}$, and Kofand Anwar ${ }^{2}$ \\ ${ }^{I}$ Business Administration, Lebanese French University. Erbil, Kurdistan. \\ ${ }^{2}$ Lebanese French University. Erbil, Kurdistan.
}

\begin{abstract}
In today's competitive business environment advertisement and constant promotion techniques are being frequently used to motivate purchasers and attract them to purchase a particular product. The study aimed to examine the relationship between types of advertisement with consumer purchasing choice in retailer stores in Erbil. The researchers gathered data through questionnaires from randomly selected customers; however 268 purchasers were involved in the current study. The findings revealed that the highest value was for online advertisement has the strongest relationship with consumer purchasing choice in retailer stores in Erbil, on the other hand outdoor advertisement has the weakest relationship with consumer purchasing choice in selecting certain retailer store in Erbil. Retailer stores should to keep up with market development to enable attracts customers. The marketplace is currently in the internet generation which indicates that retailer stores should invest more efforts and time in creating effective social media connections and provide online shopping to the customer to get closer.
\end{abstract}

Keywords: advertisement, Retailer stores, consumer choice, Erbil

\section{INTRODUCTION}

Today, almost all businesses are relying on tools and types of advertisement aiming increasing the purchasers' attractiveness as result increasing revenue. Among all the marketing techniques, advertisement is well recognized for having a long lasting influence on purchasers. Successful enterprises spend huge amount every year on advertising the products and services (Runi \& Sharma, 2014). Previous scholars and academicians have been conducted on domain of advertisement in order to clarify the purpose of advertisement. According to (Fatima, 2015) advertisement is a powerful instrument that influence individual's purchasing willingness and behaviour. In order to business survive and development in a competitive market environment, it is necessary to generate enough sales to cover operating cost and make a reasonable amount of profit. The importance of sales on business survival and the connection between customers and sales, it's necessary for organizations to engage in advertising campaigns that can influence consumers' decision to purchase its' products. Today advertisement has become one of the major sources of communication tool between businesses and purchasers of products/services. Generally, advertisement is considered as an essential element for success of any business. There are various kinds of advertisements business can use, for instance online advertising which includes social media, broadcast advertising which includes television and radio, product placement advertising which includes ads displayed through shows and movies outdoor advertising which includes events and billboards, and print advertising which includes brochures magazines and newspapers. The main purpose of advertising is to increase purchasers' 
attractiveness and willingness to purchase particular product or service. The influence of advertising is general assessed by the effectiveness of the messages defined as a degree to which the assumed objective of the advertising was achieved (Pashkevich, et al., 2012). Advertising as promotional marketing strategy, can serve as main marketing instrument in creating product or service awareness in the purchasers' mind and influencing their purchasing decision. Generally purchasers perceive the products' quality by gathering the information which they obtain from advertisements. One of the main challenges that businesses are facing today, is influencing consumers' opinion and thought in regard of particular product or service. In Erbil, the many new retailer stores are increasing existing in the marketplace this resulting in creating a competition market environment. In order to a retailer store be able to attract more purchasers, an effective advertisement should be formulated and implemented. In order to attract the potential purchasers, businesses should create a well structured advertisement campaigns.

\section{CONCEPTUAL FRAMEWORK}

\section{Research Model}

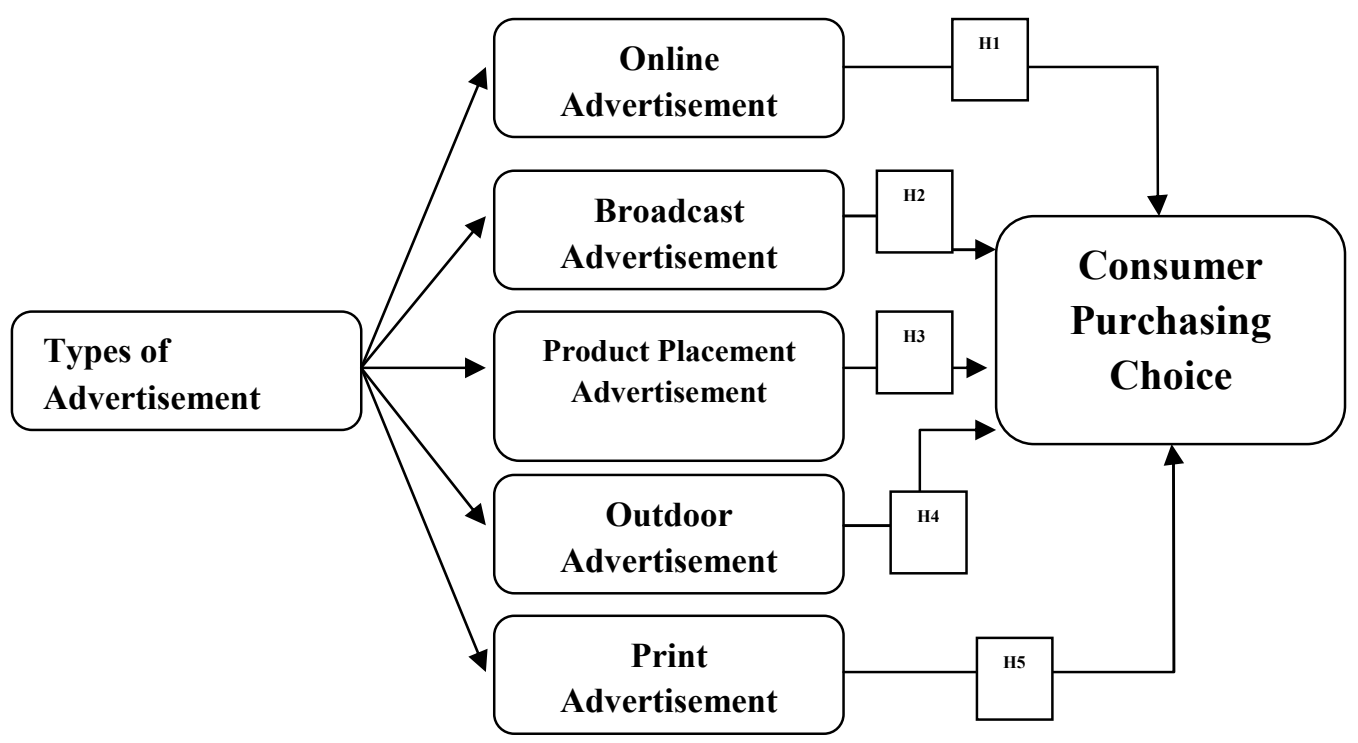

$\underline{\text { Independent Variables }}$

$\underline{\text { Dependent Variables }}$

Figure 1- Research Mode, developed by the researchers, 2017

\section{Research Hypotheses}

H1: There is a significant and positive relationship between online advertisement and consumer purchasing choice in retailer stores in Erbil.

H2: There is a significant and positive relationship between broadcast advertisement and consumer purchasing choice in retailer stores in Erbil.

H3: There is a significant and positive relationship between product placement advertisement and consumer purchasing choice in retailer stores in Erbil.

H4: There is a significant and positive relationship between outdoor advertisement and consumer purchasing choice in retailer stores in Erbil. 
H5: There is a significant and positive relationship between print advertisement and consumer purchasing choice in retailer stores in Erbil.

\section{LITERATURE REVIEW}

\section{The concept of Advertisement}

Generally advertising is mass media content planned to persuade audiences of viewers, listeners, or readers to take an action in purchasing particular product or services. According to Pikas \& Sorrentino, (2014), advertisement is as an instrument utilized to convey information concerning product or service to a target audience. Rezvan, et al., (2016), stated that an advertisement is an integral part of the marketing between product and the market which aid in generating quick sales by reaching beyond geographical boundaries in motivating the purchase of the product. Accordingly, advertisement assists purchasers to understand the deep association between brand, enterprise and purchasers. Siddiqui, et al., (2016), stated that advertisement is an influential and it facilitates purchasers' decision making while choosing a particular brand resulting increasing market value for the enterprise. This study aims to investigate five types of advertisement and its relationship with consumer purchasing choice:

\section{Online Advertisement}

The Internet advertisement and especially social media advertisement have changed how purchasers and marketers communicate (Soba \& Aydin, 2013). Online advertisement enables enterprises to reach and influence purchasers from all over the world and affect their purchasing decision. Upadhyaya, (2015) stated that rapid enlargement of online advertisement revenues indicates the capability of international web advertising as a substitute to traditional method considering internet advertising growth. Today, most of retailer stores are attracted towards online advertisement due to online advertisement has rapidly developed in the last decade (Fa \& Ja, 2015). Social media has numerous advantages as it assists connect retailers to purchasers, develop relations and promote this association in a timely manner with a low cost as Vinerean, et al., (2013). Social media advertisement differs from other types of advertisement; it has a massive popularity that has revolutionized marketing practices such as advertising and promotion (Zhang, 2015). In order to create an effective online advertisement strategy, businesses should have a strong connection with Twitter, YouTube and Facebook to attract and get closer to the potential purchasers as a result influencing their purchasing choice in a particular product or service.

\section{Broadcast Advertisement}

In the last decade, almost all individuals focus on TV all upper and middle classes even in the poorer society of urban areas and rural households (Hanif, et al., 2010). Television advertisement provides necessary information concerning a particular product or service and it enables purchasers to decide upon products or services. According to Awad, (2015), purchasers' reactions to TV advertisements found to be more successful than reactions to other types of advertisements. Furthermore, the marketers found that TV advertisement is more effective rather than print media to reach purchasers. Advertising through Television allows marketers to show and tell a wide audience concerning a product, service or retailer store. The advantage of television advertisement over the other mediums is that it is perceived as a mixture of audio and video features; it provides products with instant validity and fame and offers the greatest chance for creative advertising (Mikolajczyk, 2015). 


\section{Product Placement Advertisement}

According to (Mughal, et al., 2014) a product placement advertisement is the paid enclosure of branded products, through visual or audio instrument indicates within mass media programming. Furthermore, Nguyen, et al., (2015),stated that purchasers have a positive attitude toward product placement with some exceptions of placement of illegal for instance cigarettes, alcohol and drugs. In order to attract purchasers' attention, marketers have purposefully placed products or brand names into movies or TV scripts (Awan, et al., 2016). As more purchasers attempted to avoid advertisements, there has been development in brand placement: the practice of integrating brands into entertainment media, particularly television and film (Desai, 2014). Some of the marketers have placed their brands or products into video games that ideally fit with their brands or products (Deshwal, 2016). For instance, car manufacturer provides various models of racing car choices in car-racing games; other companies place the billboard in the background of the computer game FIFA International Soccer.

\section{Outdoor Advertisement}

Outdoor advertisement compromises advertising on signboards or bill boards, outside of a building and usually by the roadside. Many previous scholars concentrated on the effectiveness of outdoor advertising, mainly recognition and recall (e.g., Fitts and Hewett, 1977, Hassan, 2015). Increasing competition and product proliferation, overcapacity, and changing purchasers' expectations are some issues that have changed the competitive landscape of the outdoor marketplace (Kim, et al., 2011). Regardless of revenue enlargement, conversely, outdoor advertising remains "one of the least researched of any mass medium" (Kit \& P'ng, 2014). The development of outdoor advertising has incorporated a considerable increase in the utilizing of modern formats, comprising; transit such us airports, buses; alternative media such us marine, airborne, stadiums, and street furniture such us kiosks and shelters.

\section{Print Advertisement}

Print advertisement is an advertising instrument that has been utilized by numerous enterprises to promote and support their products or services. Many advertisers utilizing print media published their advertisements to attract purchasers through point-of-purchases, newspapers, magazines and more (Kofi, et al., 2015). Kofi, et al., (2015), stated that print advertisement outcome is affected by purchasers' attitudes towards advertising in general. Print media is recognized to have a significant role in informing and shaping individual's attitudes (Jan, 2002). Furthermore, print advertisement is available all the time and easy to access (Latif, 2011). Many scholars and academicians proved that print advertisement has a significant and positive influence of color print advertisement concerning of purchasers behaviour and organization's revenue (for instance, attitude toward the advertising or willingness to purchase (Owusu \& Nyarku, 2014).

\section{METHODOLOGY}

The researchers utilized a quantitative method in order to analyze the study. The research study aims to emphasize the relationship between types of advertisement purchasers' choice in retailer stores in Erbil. In order to gather data from participants, the researchers executed random sampling method to cover and provide a chance to the entire research population to be involved in the study. The researchers gathered data from different retailer stores in Erbil. A total of 300 questionnaires were distributed in Erbil city focusing on retailer stores, however 268 questionnaires were received and being completed properly. The questionnaire was utilized to collect relevant information concerning the relationship between types of advertisement on consumer purchasing choice. The first section of the survey contained demographic information 
such as gender and age of participants. The second section of the survey contained questions regarding the 5 independent variables such as; online advertisement, broadcast advertisement, product placement, outdoor advertisement and print advertisement, on the other hand the consumer purchasing choice used as dependent variable. Each independent variable's question was laid out to assess the relationship of each variable with consumer purchasing choice. The questionnaire consisted of 40 questions; three personal information questions, five questions regarding the online advertisement, five questions regarding the broadcast advertisement, five questions regarding the product placement, five questions regarding the outdoor advertisement and print advertisement and nine consumer purchasing choice questions. In order to evaluate consumer purchasing choice in retailer stores in Erbil, this research examined and assessed the relationship between types of advertisement consumer purchasing choice. The questionnaire was adapted from previous studies (Hampel, et al., 2012, Hameed , et al., 2014, Habib,et al., 2015), the respondents were asked to rate how much they agree on each item according to the five point likret scales, ranging from $1=$ Strongly Disagree to 5= Strongly Agree

\section{DATA ANALYSIS}

Table 1- Demographic Analysis
\begin{tabular}{|l|c|c|c|c|}
\hline No & Information & Items & Frequency & Percentage \\
\hline \multirow{3}{*}{$\mathbf{2}$} & Gender & Male & 159 & 59.3 \\
\cline { 3 - 5 } & & Female & 109 & 40.7 \\
\hline \multirow{4}{*}{ Age } & $\mathbf{2 0 - 2 5}$ & 29 & 10.8 \\
\cline { 3 - 5 } & & $\mathbf{2 6 - 3 0}$ & 43 & 16.0 \\
\cline { 3 - 5 } & & $\mathbf{3 1 - 3 5}$ & 78 & 29.1 \\
\cline { 3 - 5 } & & $\mathbf{3 6 - 4 0}$ & 68 & 25.4 \\
\cline { 3 - 5 } & & $\mathbf{4 1 - 4 5}$ & 21 & 7.8 \\
\cline { 3 - 5 } & & $\mathbf{4 6 - 5 0}$ & 18 & 6.7 \\
\cline { 3 - 5 } & & $\mathbf{5 0}+$ & 11 & 4.1 \\
\hline
\end{tabular}

Source, by the author, 2017

Table 1 demonstrates the demographic analysis for the participants; it was found that 159 male participants participated in this study and 109 participants participated, moreover it was found different aged of participants participated as follow; 29 participants fall into group of 20-25 years old, 43 participants fall into group of 26-30 years old, 78 participants fall into group of 3135 years old, 68 participants fall into group of 36-40 years old, 21 participants fall into group of 41-45 years old, 18 participants fall into group of 46-50-years old and 11 participants fall into group of 50 years and above.

Table 2- Reliability Analysis

\begin{tabular}{|c|c|}
\hline Variables & Cronbach's Alpha \\
\hline Online Advertisement & .797 \\
\hline Broadcast Advertisement & .801 \\
\hline Product Placement Advertisement & .798 \\
\hline Outdoor Advertisement & .719 \\
\hline Print Advertisement & .802 \\
\hline Consumer Purchaser Choice & .821 \\
\hline
\end{tabular}

The reliability analysis is illustrated in table 2, It was found the alpha for online advertisement $=.797$ this value is higher than .6 , this indicates that all items utilized to measure online advertisement were considered to be reliable in this study, the alpha for broadcast advertisement $=.801$ this value is higher than .6 , this indicates that all items utilized to measure 
broadcast advertisement were considered to be reliable in this study, the alpha for product placement advertisement $=.798$ this value is higher than .6 , this indicates that all items utilized to measure product placement advertisement were considered to be reliable in this study, the alpha for outdoor advertisement $=.719$ this value is higher than .6 , this indicates that all items utilized to measure outdoor advertisement were considered to be reliable in this study, the alpha for print advertisement $=.802$ this value is higher than .6 , this indicates that all items utilized to measure print advertisement were considered to be reliable in this study, and the alpha for consumer purchasing choice $=.821$ this value is higher than .6 , this indicates that all items utilized to measure consumer purchasing choice were considered to be reliable in this study.

Table 3-Correlation Analysis

\begin{tabular}{|c|c|c|c|c|c|c|c|}
\hline \multicolumn{8}{|c|}{ Correlations } \\
\hline & & $\begin{array}{c}\text { Consumer } \\
\text { Purchasing } \\
\text { Choice }\end{array}$ & Online & $\begin{array}{c}\text { Broadca } \\
\text { st }\end{array}$ & $\begin{array}{c}\text { product } \\
\text { placeme } \\
\text { nt }\end{array}$ & $\begin{array}{c}\text { Outdoo } \\
r\end{array}$ & Print \\
\hline \multirow{3}{*}{$\begin{array}{l}\text { Consumer } \\
\text { Purchasing } \\
\text { Choice }\end{array}$} & $\begin{array}{l}\text { Pearson } \\
\text { Correlation }\end{array}$ & 1 & & & & & \\
\hline & $\begin{array}{l}\text { Sig. (2- } \\
\text { tailed) }\end{array}$ & & & & & & \\
\hline & $\mathrm{N}$ & 268 & & & & & \\
\hline \multirow[t]{3}{*}{ Online } & $\begin{array}{l}\text { Pearson } \\
\text { Correlation }\end{array}$ & $.816^{* *}$ & 1 & & & & \\
\hline & $\begin{array}{l}\text { Sig. (2- } \\
\text { tailed) }\end{array}$ & .000 & & & & & \\
\hline & $\mathrm{N}$ & 268 & 268 & & & & \\
\hline \multirow[t]{3}{*}{ broadcast } & $\begin{array}{l}\text { Pearson } \\
\text { Correlation }\end{array}$ & $.585 * *$ & $.377 * *$ & 1 & & & \\
\hline & $\begin{array}{l}\text { Sig. (2- } \\
\text { tailed) }\end{array}$ & .000 & .006 & & & & \\
\hline & $\mathrm{N}$ & 268 & 268 & 268 & & & \\
\hline \multirow[t]{3}{*}{$\begin{array}{l}\text { Product } \\
\text { placement }\end{array}$} & $\begin{array}{l}\text { Pearson } \\
\text { Correlation }\end{array}$ & $.683 * *$ & $.527 * *$ & $.873 * *$ & 1 & & \\
\hline & $\begin{array}{l}\text { Sig. (2- } \\
\text { tailed) }\end{array}$ & .000 & .000 & .000 & & & \\
\hline & $\mathrm{N}$ & 268 & 268 & 268 & 268 & & \\
\hline \multirow[t]{3}{*}{ Outdoor } & $\begin{array}{l}\text { Pearson } \\
\text { Correlation }\end{array}$ & $.588 * *$ & $.442 * *$ & $.325 *$ & $.563 * *$ & 1 & \\
\hline & $\begin{array}{l}\text { Sig. (2- } \\
\text { tailed) }\end{array}$ & .000 & .001 & .020 & .000 & & \\
\hline & $\mathrm{N}$ & 268 & 268 & 268 & 268 & 268 & \\
\hline \multirow[t]{3}{*}{ Print } & $\begin{array}{l}\text { Pearson } \\
\text { Correlation }\end{array}$ & $.724 * *$ & $.625 * *$ & $.415 * *$ & $.672 * *$ & $.733 * *$ & $\begin{array}{c}.621^{*} \\
*\end{array}$ \\
\hline & $\begin{array}{l}\text { Sig. (2- } \\
\text { tailed) }\end{array}$ & .000 & .000 & .002 & .000 & .000 & .000 \\
\hline & $\mathrm{N}$ & 268 & 268 & 268 & 268 & 268 & 268 \\
\hline
\end{tabular}

The above table 3 demonstrates the correlation between dependent variable and each independent variables; the results of correlation analysis revealed that the Pearson correlation between online advertisement and consumer purchasing choice $=.816^{* *}$, this indicates that the value of correlation is significant at the 0.01 level (2-tailed), the Pearson correlation between 
broadcast advertisement and consumer purchasing choice $=. .585^{* *}$, this indicates that the value of correlation is significant at the 0.01 level (2-tailed), the Pearson correlation between product placement advertisement and consumer purchasing choice $=.683^{* *}$, this indicates that the value of correlation is significant at the 0.01 level (2-tailed), the Pearson correlation between outdoor advertisement and consumer purchasing choice $=.588^{* *}$, this indicates that the value of correlation is significant at the 0.01 level (2-tailed) and the Pearson correlation between print advertisement and consumer purchasing choice $=. .724^{* *}$, this indicates that the value of correlation is significant at the 0.01 level (2-tailed). However, the results of correlation analysis revealed that all independent variables are significantly correlated with consumer purchasing choice; it was found that the highest value was the correlation between online advertisement and consumer purchasing choice on the other hand the lowest value was the correlation between broadcast advertisement and consumer purchasing choice.

Table 4-Multiple Regression Analysis

\begin{tabular}{|c|c|c|c|c|c|c|}
\hline \multicolumn{7}{|c|}{ Coefficients $^{\mathrm{a}}$} \\
\hline \multirow{2}{*}{\multicolumn{2}{|c|}{ Model }} & \multicolumn{2}{|c|}{$\begin{array}{l}\text { Unstandardized } \\
\text { Coefficients }\end{array}$} & \multirow{2}{*}{$\begin{array}{l}\text { Standardized } \\
\text { Coefficients } \\
\text { Beta }\end{array}$} & \multirow[t]{2}{*}{$\mathrm{t}$} & \multirow[t]{2}{*}{ Sig. } \\
\hline & & $\mathrm{B}$ & $\begin{array}{l}\text { Std. } \\
\text { Error }\end{array}$ & & & \\
\hline \multirow[t]{6}{*}{1} & (Constant) & .117 & .145 & & .805 & .425 \\
\hline & Online & .024 & .004 & .560 & 6.652 & .000 \\
\hline & Broadcast & .303 & .106 & .437 & 2.848 & .000 \\
\hline & $\begin{array}{l}\text { Product } \\
\text { placement }\end{array}$ & .158 & .123 & .246 & 1.285 & .035 \\
\hline & Outdoor & .081 & .049 & .160 & 1.635 & .109 \\
\hline & Print & .186 & .094 & .242 & 1.993 & .052 \\
\hline & R Square & \multicolumn{5}{|c|}{.813} \\
\hline & $\mathrm{F}$ & \multicolumn{5}{|c|}{39.184} \\
\hline
\end{tabular}

a. Dependent Variable: Consumer Purchasing Choice

The researcher utilized multiple regression analysis, generally to find the relationship between each types of advertisement and consumer purchasing choice, particularly to find which advertisement type has stronger relationship than another type. However, the results of multiple regression analysis (Table 4, in Appendix B) revealed that the Beta value $=.560$ with significant level of .000 , this indicates that online advertisement has positively and significantly predict consumer purchasing choice as result first research hypothesis supported. As for broadcast advertisement, it was found that the value of Beta $=.437$ with significant level of .000 this indicates that broadcast advertisement has positively and significantly predict consumer purchasing choice as result second research hypothesis supported. Concerning product placement, the value of Beta $=.246$ with significant level of .035 which is higher than .000 this indicates that product placement advertisement has positively but not significantly predict consumer purchasing choice as result third research hypothesis rejected. Concerning outdoor advertisement, the value of $B e t a=.160$ with significant level of .109 which is higher than .000 this indicates that outdoor advertisement has positively but not significantly predict consumer purchasing choice as result fourth research hypothesis rejected, and Concerning print advertisement, the value of $\mathrm{Beta}=.242$ with significant level of .052 which is higher than .000 this indicates that print advertisement has positively but not significantly predict consumer purchasing choice as result third research hypothesis rejected. The results of multiple regression 
analysis revealed that the highest value was for online advertisement has the strongest relationship with consumer purchasing choice in retailer stores in Erbil, on the other hand outdoor advertisement has the weakest relationship with consumer purchasing choice in selecting certain retailer store in Erbil.

\section{DISCUSSION}

Results revealed that some of advertisement techniques have a significant influence and relationship with consumer purchasing choice. Generally, advertisement has significant and positive relationship with consumer purchasing choice; however some of respondents preferred certain types of advertisement to be better and more effective than other sort of advertisement. Advertisement assists and guides customers to make the correct decision during their purchasing process in retailer stores. Based on the findings, the researchers concluded that; online advertisement has a positive and significant relationship with consumer purchasing choice. Advertisement on social media has highly affect on consumers which enable them to find out many ads in regard of retailer stores' promotion, discounts, new brands and etc. as a result of interaction and spread of opinions between customers they make their purchasing choices. (Vinerean, et al., 2019). Accordingly store managers are recommended to put efforts and develop an effective plan to create a successful social media sites to impact online shopping by identifying and targeting different types of customers and taking initiatives to recognize and highlight customer interests. The second highest advertisement was found to be broadcast advertisement, the results revealed that broadcast advertisement has significant and positive relationship with on consumer purchasing choice, Erbil residency found that broadcast advertisement to be an informative source of new products and existing products and it has an impact on how they make their purchasing choices but this type is not as effective as other methods. (Krishnakumar and Radha, 2014) also concluded that a maximum level of respondents is giving positive impact on effectiveness of TV Ads on consumer purchase decision. Furthermore, the results demonstrates that retailer stores' advertisements and chose online ads to be the most influential factor that motivated them to shop at the hypermarket. (Darban and Li, 2012) concluded from their findings that consumers perceive online social networks as an information source when they want to make purchasing in food retailer shops; and nowadays they gradually replacing the search engines sites by Facebook. Consumers have more faith and feel closer to the company when interacting with supermarkets on Facebook and this affects their consumer purchasing choice.

\section{CONCLUSION}

This research demonstrates the significance of advertisement and its relationship with consumer purchasing choice in retailer stores in Erbil. Although that there are many previous researchers studied the relationship between types of advertisement and consumer choice, however only some scholars focused on retailer store and choosing certain store based on the advertisement. The findings revealed that the highest value was for online advertisement has the strongest relationship with consumer purchasing choice in retailer stores in Erbil, on the other hand outdoor advertisement has the weakest relationship with consumer purchasing choice in selecting certain retailer store in Erbil. Retailer stores should to keep up with market development to enable attracts customers. The marketplace is currently in the internet generation which indicates that retailer stores should invest more efforts and time in creating effective social media connections and provide online shopping to the customer to get closer. 


\section{REFERENCES}

Awad Alhaddad, A. (2015). The Effect of Advertising Awareness on Brand Equity in Social Media. International Journal of E-Education, E-Business, E-Management and E-Learning, 5(2), 73-84. https://doi.org/10.17706/ijeeee.2015.5.2.73-84

Awan, A. G., Ismail, M., Majeed, F., \& Ghazal, F. (2016). Effects of Advertisement on Consumer's Buying Behaviour with References to FMCGs in Southern Punjab-Pakistan. Journal of Marketing and Consumer Research, 19(2015), 22-30.

Desai, K. (2014). A Study on Consumer Buying Behaviour of Cosmetic Products in Kolhapur. Reviews of Literature, 1(10), 2347-2723

Deshwal, P. (2016). Online Advertising and its Impact on Consumer Behavior, International Journal of Applied Research. 2(2), 200-204.

Rani N., Sharma V,(2014). the Impact of Television Commercials on Purchasing Behaviour of Masses, International Journal of Science and Research. 5(1), 2-5.

Fa, I., \& Ja, T. (2015). Influence of Celebrity in Television Advertising: A Study of Pepsi Consumers among Unilag Undergraduates. IOSR Journal Of Humanities And Social Science Ver. III, 20(10), 26-31. https://doi.org/10.9790/0837-201032631

Fatima, S. (2015). Impact of Advertisement on Buying Behaviours of the Consumers : Study of Cosmetic Industry in Karachi City . International Journal of Management Sciences and Business Research ISSN, 4(10), 125-137.

Hanif, M., Hafeez, S. and Riaz, A. (2010). Factors affecting customer satisfaction. International Research Journal of Finance and Economics, 60, 44-52.

Hassan, A. (2015). Effects of TV Advertisement on Consumer Buying Behaviour: A Comparative Study of Rural-Urban and Male-Female Consumers. International Journal of Innovation and Applied Studies, 11(3), 608-614.

Kim, Y., Sohn, D., \& Choi, S. (2011). Cultural difference in motivations for using social network sites: A comparative study of American and Korean college students. Computers in Human Behavior, 27(1):365-372.

Kit, L. C., \& P'ng, E. L. Q. (2014). The Effectiveness of Product Placement: The Influence of Product Placement towards Consumer Behavior of the Millennial Generation. International Journal of Social Science and Humanity, 4(2), 138-142.

Kofi, I., Ernest, N., Tsetse, K., Kojo, S., \& Avorgah, M. (2015). Is Billboard Advertising an Effective Tool in The Marketing of Home Appliances? Asian Journal of Social Sciences, 2(3), 101-108.

Krishnakumar, K., \& Radha, K. (2014). A Study on Relevance Factor in Effectiveness of Television Advertisements on Consumer Purchase Decision in Salem District. International Journal of Business and Administration, 1(2), 23-30.

Latif, Abdul and Abideen, Zain Ul. (2011). Effects of Television Advertising on Children: A Pakistani Perspective. European Journal of Economics, Finance and Administrative Sciences, , 30, 38-49

Mikolajczyk, A. (2015). Product Placement in Brand Promotion. Contemporary Economy Electronic Scientific Journal, 6(2), 11-19.

Mohan, M. (1989). Advertising Management: Concepts and Cases, Tata McGraw-Hill Education.

Mughal, A., Mehmood, A., Mohiuddeen, A., \& Ahmad, B. (2014). The Impact of Promotional Tools on Consumer Buying Behavior: A Study from Pakistan. Journal of Public Administration and Governance, 4(3), 402-414.

Nguyen, T. N., Phan, T. T. H., \& Vu, P. A. (2015). The Impact of Marketing Mix Elements on Food Buying Behavior: A Study of Supermarket Consumers in Vietnam. International Journal of Business and Management, 10(10), 206-215. 
https://doi.org/10.5539/ijbm.v10n10p206

Owusu, D., \& M. Nyarku, K. (2014). Influence of Print Advertising on the Decisions of Tertiary Students to Purchase Telecom Products in the Cape Coast Metropolis: The Moderating Role of Price and Service Quality Delivery. International Journal of Academic Research in Business and Social Sciences, 4(10), 314-332. https://doi.org/10.6007/IJARBSS/v4i10/1229

Pashkevich, M., Dorai-Raj, S., Kellar, M., \& Zigmond, D. (2012). Empowering Online Advertisements by Empowering Viewers with the Right to Choose The Relative Effectiveness of Shippable Video Advertisements on YouTube. Journal Of Advertising Research, 52(4), 451-457.

Pikas, B., \& Sorrentino, G. (2014). The Effectiveness of Online Advertising: Consumer's Perceptions of Ads on Facebook, Twitter and YouTube. Jounal of Applied Business and Economics, 16(4), 70-81.

Habib, A., Hossain, S., Oma, T.,(2015). Impact of Advertisement on Consumer Choice : a Case of Sme and Consumers, Singaporean Journal Of Business Economics, And Management Studies 4(5), 1-15.

Hampel, S., Heinrich, D., \& Campbell, C. (2012). Is an Advertisement Worth the Paper It's Printed on? The Impact of Premium Print Advertising on Consumer Perceptions. Journal of Advertising Research, 52(1), 118-127. https://doi.org/10.2501/JAR-52-1-118-127

Rezvan, N. S., Norouzi, H., \& Firouzi, Z. (2016). The Study of Outdoor Advertisements Effects on Behavioral Mechanisms of Final Consumers in Food Industry of Iran, International Journal of Business and Industrial Marketing, 1(5), 95-100.

Siddiqui, K. A., Sher, S., Tarani, A., Fatani, S. A., Raza, A., \& Muzamil, R. (2016). Effect of Size, Location and Content of Billboards on Brand Awareness, Journal of Business Studies Quarterly, 8(2).

Soba, M., \& Aydin, M. (2013). Product Placement Efficiency in Marketing Communication Strategy. International Journal of Business and Management, 8(12), 111-116. https://doi.org/10.5539/ijbm.v8n12p111

Upadhyaya, M. (2015). The Impact of Humorous Television Advertisement In Customer Opinion In Bahrain. Indian Journal of Commerce \& Management Studies, VI(3), 5674.

Vinerean, S., Cetina, I., Dumitrescu, L., \& Tichindelean, M. (2013). The Effects of Social Media Marketing on Online Consumer Behavior. International Journal of Business and Management, 8(14), 66-79. https://doi.org/10.5539/ijbm.v8n14p66

Zhang, Y. (2015). The Impact of Brand Image on Consumer Behavior: A Literature Review. Open Journal of Business and Management, 3(1), 58-62. https://doi.org/10.4236/ojbm.2015.31006 